\title{
Alternative Automobile Pollution Control Policies: Perspective of Motorists in Owerri Municipal of Imo State, Nigeria
}

\author{
Godwin Nneji Okere \\ Keyna C. Nwachukwu \\ Veronica O. Ezebuiro
}

\author{
Department of Physical \& Health Education \\ Alvan I koku Federal College of Education, Owerri, Imo State, Nigeria
}

\section{Doi:10.5901/jesr.2013.v3n4p9}

\begin{abstract}
Literature indicates that present policies on environmental protection tend to impose cumbersome and rigid regulations which are often highly uneconomic for all stakeholders in pollution abatement. The reason is that the role of the tax system as a deterrent and motivator of behaviour, economic penalties or a combination of these approaches seem not have been adequately studied prior to formulation of policies and promulgation of legislations for environmental pollution abatement. This research therefore was designed to investigate the perception of motorists in Owerri Municipal Council of Imo State on the utilization of economic incentives or penalties as policy alternatives to encourage abatement of automobile pollution. The cross sectional survey design was adopted for the study. To achieve the research goal, a comprehensive questionnaire was developed and administered to two hundred and nine motorists in the survey area. The random sampling method was used to select the subjects from three out of the five communities in Owerri Municipal. One hundred and twenty four questionnaires were duly completed and used for the analysis. The major finding of this study was that the subjects provided a consensus response that requires passage and strict enforcement of laws requiring automobile importers to import only cars which meet antipollution standards. It was therefore concluded that automobile emission control failures can only be resolved by automobile manufacturers and importers. It was thus recommended that Air Resources Commission should be established in Nigeria with the responsibility of regulating emissions from all fueled and gasoline burn engines imported into the country, while importers whose automobiles pass emission tests should be given free tax.
\end{abstract}

Keywords: Automobile; Motorists; Pollution; Environment; Emissions

\section{Introduction}

The importation and excessive reliance on the use of automobile in Nigeria during recent history, although have numerous benefits to human life, the benefits, however, have been accompanied by changes in the environment detrimental to man. In numerous cities across Nigeria, driving private car is probably a typical citizen's most "polluting" daily activity, as emissions from millions of personal vehicles on the road add up. Automobile exhaust emission has been found to be the most widespread and intractable urban air pollution problem (U.S Environmental Protection Agency Office of Mobile Sources, 2007). 
To see automobile emission problem in Nigeria in proper perspective, the shores of Nigeria were kept wide open for importation of fairly used cars popularly called "Tokunbo" cars, by the Obasanjo administration of 1999 to 2007. Sequel to increase in workers' salary by this administration, and the corresponding rise in socio-economic status, automobile importation skyrocketed. In Imo State, the Governor Ohakim's clean and green concept (Ohakim, 2008) encompass the ban of motor cycle in Owerri Urban and the introduction of multitude of tricycles popularly known as "Pepper na keke" and "Kim Kim" as an alternative means of transportation. This scenario worsened the already chaotic traffic congestion in Owerri, and increased automobile emissions and air pollution.

Hines (2006) recalled when in history, sequel to automobile emission, Los Angeles city experienced air shed, climate change and obscuring of the sun causing eyes to smart and stuffedup noses. Exhaust pollutants; hydrocarbons, nitrogen oxides $\left(\mathrm{No}_{\mathrm{x}}\right)$, carbon monoxide and carbon dioxide exert deleterious effects on human health and the environment (U.S. Environmental Protection Agency Office of Mobile Sources, 2007). Hydrocarbons react in the presence of nitrogen oxides and sunlight to form ground-level ozone. Ozone irritates eyes and damages the lungs. A number of hydrocarbons are toxic, with the potential to cause cancer. Under the high pressure and temperature conditions in an engine, nitrogen and oxygen atoms in the air react to form various nitrogen oxides, which also are precursors to the formation of ozone. They contribute to the formation of acid rain. Carbon monoxide (CO) reduces the flow of oxygen in the blood stream and is particularly dangerous to persons with heart disease. Carbon dioxide does not directly impair human health but it is a "greenhouse gas" that traps the earth's heat and contributes to the potential for global warming (EPA National Vehicle and Fuel Emissions Laboratory Report (2009), with solastolgic effects.

It is thus, estimated that transportation contributes to 56.6 percent of nitrogen oxide, 86.6 percent of hydrocarbons, 97.5 percent of carbon monoxide and 25.6 percent of particulates of air pollution problems (Oklahoma State Health Department, 2005). Sridher (1994) observed that fumes produced annually in Nigeria by several millions of combustion engines of automobiles, trucks and buses contribute to more than 40 percent of all air pollution emissions and over 60 percent of all carbon monoxide released into the Nigeria environment. The author (Sridher, 1994) reported that in a study conducted in Ibadan, Nigeria; it was shown that carbon monoxide levels were more in traffic congested areas. Researchers (Koning 1994; Ogbodo \& Ogunbunmi, 1997) identified lead in "Molue" fumes in Lagos State as the greatest environmental threat.

Harrison (1990), Taniniwivo (2011) and Bordoff (2011) identified automobile emissions as the major sources of lead poisoning which mostly affect children and pregnant women. Hussein (2000) observed that automobile air pollution has one of the major effects on humans, animals and vegetation. Lead from exhaust causes systemic poisoning (Waldbolt, 2008). Organic compounds found in diesel are suspected to be mutagenic (causing mutations in genes) or teratogenic (causing birth abnormalities) (Council on Environmental Quarterly, 1998). Asthma, bronchitis, emphysema and lung cancer are attributed to air pollutants (Sridher, 1994). These disorders may be higher where automobile air pollution combines with burning of refuse, bush, firewood, kerosene, oils and other sources of air pollution including generators. Gallion (2007) in a synopsis estimates that 88 percent of the air problem in a city like Oklahoma, U.S.A was caused by the operation of motor vehicles.

Although automobile air pollution constitutes one of the common environmental problems in Owerri, I mo State capital, it is not as great as in the case of more populous and industrial states like Lagos, Kaduna, Ibadan and so on. In a real sense the state has golden opportunity to learn from the misfortune of these older states in dealing with the present awakening to air quality and should be better prepared than most of those states were.

The tasks of setting air quality goals, implementing and enforcing air quality improvement programmes seem to be glossed over by both federal and state governments in Nigeria. The attention of the government policies and prograqmmes tend to be primarily on water pollution 
control, solid waste management and part of pesticide and radiation control. Minimal emission control regulation is given to the control of automobile emissions.

There are however, several possible approaches to achieve air ambient standards. The most obvious approach and the only major one which many countries including Nigeria relied heavily is government regulation. Various studies and popular opinions lately seem to indicate that another major alternative to government regulation is the use of economic incentives or penalties

However, there seems to be a major lack of basic research and studies about the concept of using economic incentives or penalties as a tool to control automobile pollution and thus, achieve ambient standard of air quality in Nigeria. Using the tax system in combination with regulations and legislation is probably one of the many alternatives that the Nigerian motorists and tax payers must consider in order to win the war for a cleaner air quality. In a profit-motivated economy like Nigeria, economic incentives tend to act as a veritable tool for motivation of a desirable behaviour. This is not to say, however, that regulations are not feasible (Howard-Clinton, 2005)

\section{Statement of the problem}

At the present, health and environmental officials have observed that 90 percent of the air pollution problem is caused by the automobile. It has been projected that if the rate of ownership of individual automobiles continues to increase, 30 years from now, in the year 2042 AD, 9 out of every 10 citizens will own a car. Pollution by automobiles will triple. Air pollution caused by motor car will be a major problem in urban areas. It is known that eye irritation, emphysema, cancer and other respiratory infections are all associated with the problem of air pollution. Currently, policies for automakers and importers have not controlled emission. This study therefore, was predicated on the absence of empirical data which various states and academic community can rely on as a source of initiating alternatives of solving automobile pollution within urban areas in Nigeria.

\section{Purpose}

The purpose of this study therefore, was to investigate the preference of motorists in Owerri Municipal Council concerning selected policies for the abatement of automobile pollution.

\section{Hypotheses}

The following hypotheses were formulated to guide the study:

1. There is no significant difference in preference to automobile pollution control measures between male and female motorists in Owerri Municipal Council.

2. There is no significant difference in preference to automobile pollution control measures among motorists of different age groups in Owerri Municipal Council.

3. There is no significant difference in preference to automobile pollution control measures between motorists in Owerri Municipal Council with secondary school education and those without secondary school education.

4. There is no significant difference in preference to automobile pollution control measures between white and blue collar motorists in Owerri Municipal Council.

\section{Research Methods}

The cross-sectional survey design was adopted for the study. The physical area of the research survey consisted of the Owerri Municipal Corporate boundary area, with a 2006 population projection of 14,010 males and 16.192 females. The sample consisted of 209 motorists. 
For the purpose of this study, the established division of streets and roads in Owerri was used to cluster the corporate city limit into five traditional communities namely, Amawom, Umuoyima, Umuodu, Umuoronjo and Umuonyeche. Three out of the five villages, Amawom, Umuororonjo and Umuodu were selected via random sampling without replacement.

The list of the roads/streets in each chosen community was compiled. In order to systematically select from the list of roads/streets in each community, a coin was tossed. The coin came down tail; the investigator started with the first even numbered digit which was 2 to begin the systematic selection of streets/roads. This procedure yielded 45 streets/roads in the three communities. Each street was further divided into compounds. The compounds were numbered; the total number was 2001 with 3,315 households. The purposive sampling technique was employed at this stage to draw a sample of 209 motorists in line with Nworgu (1991) assertion that purposive sampling technique ensures that only elements relevant to the research are included and guarantees that extra care is taken to select those elements that satisfy the requirements of the research.

The research instrument utilized was a self-designed "story telling" technique type questionnaire. The reliability index of the instrument resulting from Spear-man rank order correlation coefficient formula was 0.74 . The instrument was then administered with the assistance of final year health education degree students of the researcher.

After receiving 124 duly completed questionnaires, which is a 59.3 percent return ratio, the responses were analysed to describe the alternative automobile emission control measures Owerri Municipal Council motorists were willing to use as major policy tool to achieve ambient air quality. Chi-square statistical formula was used to test the statistical significance level of the various demographic variables at 0.05 level of significance.

\section{Findings}

The findings of the study are presented in the tables below. 
Table 1: Sex and Preference to Automobile Pollution Control Measures among Motorists in Owerri Municipal Council

\begin{tabular}{llll}
\hline Possible Automobile Pollution Control Measures & Male & Female & Total \\
\hline
\end{tabular}

Item I: Pass and enforce laws that require automobile Importers to import automobiles which meet approach, present method).

$\begin{array}{lll}37.6 & 41.0 & 38.7\end{array}$

Item II : Give free tax to automobile companies that import cars which achieve antipollution

$\begin{array}{lll}5.9 & 5.1 & 5.6\end{array}$
standards (economic incentives).

(5) (2)

Item II I: Give free tax to automobile companies that import cars which achieve antipollution standards, then impose heavy tax penalty on auto companies which import cars that do not achieve antipollution standards (a $21.2 \quad 23.1 \quad 21.8$ combination of incentive and penalty system)

Item IV: Levy heavy tax penalties on consumers who purchase automobiles which do not meet antipollution standards.

Item V: Give free tax to consumers who purchase automobiles that achieve antipollution standards.

$\begin{array}{rcc}21.2 & 25.6 & 22.6 \\ (18) & (10) & (28) \\ & & \\ 8.0 & 0.0 & 5.6 \\ (7) & (0) & (7) \\ \mathbf{1 0 0 . 0} & \mathbf{1 0 0 . 0} & \mathbf{1 0 0 . 0} \\ (85) & (39) & (124)\end{array}$

Item VI: Government should do nothing.

Total

- Numbers in parentheses refer to number of respondents.

- $X^{2}=3.62$ with $5 \mathrm{df}$, Critical $X^{2}$ value at .05 level=11.07.

Table 1 shows that pass and enforce laws that require automobile importers to import cars which meet antipollution standards (the regulatory approach, present method) was the choice of both sex groups. The male respondents chose this item by 37.6 percent and the female by 41.0 percent. The second choice of the female subjects was item $v$ (give free tax to consumers who purchase automobiles that achieve antipollution standards), 25.6 percent, whereas, the second choice of the male group was item III, by (21.2) percent. Chi-square statistical formula was employed to test the hypothesis that there is no significant difference in preference to automobile pollution control measure between male and female motorists in Owerri Municipal Council. The hypothesis was retained on the basis of the outcome of $X^{2}=3.62$ with $5 \mathrm{df}$, Critical $X^{2}$ value at .05 level $=11.07$. 
Table 2: Age Preference to Automobile Pollution Control Measures among Motorists in Municipal Council.

\begin{tabular}{|c|c|c|c|c|c|c|c|}
\hline & Item I & Item II & Item III & Item IV & Item V & Ite m VI & Total \\
\hline$<35$ & $\begin{array}{c}22.0 \\
(8)\end{array}$ & $\begin{array}{c}2.7 \\
(1)\end{array}$ & $\begin{array}{l}36.0 \\
(13)\end{array}$ & $\begin{array}{r}11.0 \\
(4)\end{array}$ & $\begin{array}{r}27.8 \\
(10)\end{array}$ & $\begin{array}{c}0.0 \\
(0)\end{array}$ & $\begin{array}{r}100.0 \\
\quad(36)\end{array}$ \\
\hline $35-44$ & $\begin{array}{c}40.0 \\
(8)\end{array}$ & $\begin{array}{l}5.0 \\
(1)\end{array}$ & $\begin{array}{r}20.0 \\
(4)\end{array}$ & $\begin{array}{l}10.0 \\
(2)\end{array}$ & $\begin{array}{r}25.5 \\
(5)\end{array}$ & $\begin{array}{c}0.0 \\
(0)\end{array}$ & $\begin{array}{r}100.0 \\
(20)\end{array}$ \\
\hline $45-54$ & $\begin{array}{l}48.0 \\
(13)\end{array}$ & $\begin{array}{l}7.4 \\
(2)\end{array}$ & $\begin{array}{l}14.8 \\
(4)\end{array}$ & $\begin{array}{l}0.0 \\
(0)\end{array}$ & $\begin{array}{r}18.5 \\
(5)\end{array}$ & $\begin{array}{c}11.0 \\
(3)\end{array}$ & $\begin{array}{c}100.0 \\
(27)\end{array}$ \\
\hline $55-64$ & $\begin{array}{l}52.6 \\
(10)\end{array}$ & $\begin{array}{l}5.1 \\
(1)\end{array}$ & $\begin{array}{r}10.5 \\
(2)\end{array}$ & $\begin{array}{l}5.1 \\
(1)\end{array}$ & $\begin{array}{c}15.8 \\
(3)\end{array}$ & $\begin{array}{c}10.5 \\
(2)\end{array}$ & $\begin{array}{r}100.0 \\
(19)\end{array}$ \\
\hline$>65$ & $\begin{array}{c}40.9 \\
(9)\end{array}$ & $\begin{array}{l}9.1 \\
(2)\end{array}$ & $\begin{array}{c}18.1 \\
(4)\end{array}$ & $\begin{array}{l}0.0 \\
(0)\end{array}$ & $\begin{array}{l}22.7 \\
(5)\end{array}$ & $\begin{array}{l}9.1 \\
(2)\end{array}$ & $\begin{array}{r}100.0 \\
(22)\end{array}$ \\
\hline Total & $\begin{array}{l}38.7 \\
(48)\end{array}$ & $\begin{array}{l}5.6 \\
(7)\end{array}$ & $\begin{array}{l}21.8 \\
(27)\end{array}$ & $\begin{array}{r}5.6 \\
(7)\end{array}$ & $\begin{array}{l}22.6 \\
(28)\end{array}$ & $\begin{array}{l}5.6 \\
(7)\end{array}$ & $\begin{array}{l}100.0 \\
(124)\end{array}$ \\
\hline
\end{tabular}

*Numbers in parentheses refer to number of respondents.

$* X^{2}=27.82$ with $25 \mathrm{df}$. Critical value at .05 level $=37.65$.

As regards age and choice to control of automobile pollution, the data in table 2 shows that subjects under 35 years old preferred item III (give free tax to automobile companies that import cars which achieve antipollution standards, then impose heavy tax penalty on companies that import polluting automobiles, by 36.0 percent. All other age groups preferred item I (pass and enforce laws that require automobile importers to import automobiles which meet antipollution standards). The corresponding hypothesis 2 which stated that there is no significant difference in preference to automobile pollution control measures among motorists of different age groups in Owerri Municipal Council was accepted on the basis of $X^{2}$ calculated value $=27.82$ with $25 \mathrm{df}$. Critical $X^{2}$ value at .05 level $=37.65$. 
Table 3: Education and Preference to Automobile Pollution Control Measures among Motorists in Owerri Municipal Council.

\begin{tabular}{lll}
\hline Possible Automobile Pollution Control & Subjects with & Subjects with- Total \\
Measures & Secondary & out second- \\
& School & dary Educa- \\
& Education tion \\
\hline
\end{tabular}

Item I: Pass and enforce laws that require automobile importers to import automobiles which meet antipollution standards (the 35.7 regulatory approach, present method) (30)

Item II: Give free tax to automobile companies that import cars which achieve antipollution standards (economic incentives)

$\begin{array}{lll}4.8 & 7.5 & 5.6 \\ (4) & (3) & (7)\end{array}$

Item III: Give free tax to automobile companies that import cars which achieve antipollution standards, then impose heavy tax penalty on auto companies which import cars that do not achieve antipollution standards (a combination of incentive and penalty system).

Item IV: Levy heavy tax penalties on consumers who purchase automobiles which do not meet antipollution standards.

$\begin{array}{lll}5.9 & 5.0 & 5.6 \\ (5) & (2) & (7)\end{array}$

Item V: Give free tax to consumers who purchase automobiles that achieve antipollution standards.

\begin{tabular}{cccc} 
Item VI: Government should do nothing. & 5.9 & 5.2 & 5.6 \\
& $(5)$ & $(2)$ & $(7)$ \\
\hline Total & $\mathbf{1 0 0 . 0}$ & $\mathbf{1 0 0 . 0}$ & $\mathbf{1 0 0 . 0}$ \\
& $\mathbf{( 8 4 )}$ & $\mathbf{( 4 0 )}$ & $\mathbf{( 1 2 4 )}$ \\
\hline
\end{tabular}

*Numbers in parentheses refer to number of respondents.

$* X^{2}=32.83$ with $35 \mathrm{df}$. Critical value at .05 level $=49.77$.

The data in table 3 shows that those subjects with secondary school education preferred Item I by 37.7 percent and the second choice of this group was Item III, 27.4 percent. The subjects without secondary school education also chose Item I, but with a higher percentage level, 45.0. The second choice of this group was Item $\mathrm{V}$ (give free tax to consumers who purchase automobiles that achieve antipollution standard). The result $X^{2}=32.83$ with $35 \mathrm{df}$. Critical value at .05 level $=49.77$, indicates that the hypothesis which stated that there is no significant difference in preference to automobile pollution control measures between motorists in Owerri Municipal Council with secondary school education and those without secondary school education was accepted. 
Table 4: Occupation and Preference to Automobile Pollution Control Measures among Motorists in Owerri Municipal Council.

\begin{tabular}{llll}
\hline \multicolumn{3}{c}{ White } & \multicolumn{2}{c}{ Blue } \\
Collar & \multicolumn{2}{c}{ Collar } \\
Possible Automobile Pollution Control Measures & Workers & Workers & Total \\
\hline
\end{tabular}

Item I: $\quad$ Pass and enforce laws that require automobile importers to import automobiles which meet antipollution standards (the

38.8

regulatory approach, present method)

Item II: Give free tax to automobile companies that import cars which achieve anti3.6 pollution standards (economic incentives).

Item III: Give free tax to automobile companies that import cars which achieve antipollution standards, then impose heavy tax penalty on auto companies which import cars that do not achieve antipollution standards ( a combination of incentive and penalty system).

Item IV: Levy heavy tax penalties on consumers who purchase automobiles which do not meet antipollution standards.

Item V: Give free tax to consumers who purchase automobiles that achieve antipollution standards.

Item VI: Government should do nothing.

*Numbers in parentheses refer to number of respondents.

$* X^{2}=52.29$ with $45 \mathrm{df}$. Critical $X^{2}$ value at .05 level $=61.63$.

Regarding occupation and the choice of control measures to automobile emissions, the data in table 4 indicates that both the white and blue collar workers selected item I, (pass and enforce laws that require automobile importers to import automobiles which meet antipollution standards as the best alternative to control automobile emissions. The white collar group chose the item by 38.8 percent; the blue collar group chose the item by 38.1 percent. The table equally shows that items III and V were the second choices of both groups. The chi-square statistical significance level shows that the hypothesis that there is no significant difference in preference to automobile pollution control measures between white and blue collar motorists in Owerri Municipal Council was retained. 
Table 5: Family Income and Preference to Automobile Pollution Control Measures

\begin{tabular}{lllll}
\hline $\begin{array}{l}\text { Possible Automobile Pollution Control } \\
\text { Measures }\end{array}$ & $\begin{array}{l}\text { Low } \\
\text { Income }\end{array}$ & $\begin{array}{l}\text { Middle } \\
\text { Income }\end{array}$ & $\begin{array}{l}\text { High } \\
\text { Income }\end{array}$ & Total \\
\hline
\end{tabular}

Item I: Pass and enforce laws that require automobile importers to import automobiles which meet antipollution standards (the regulatory approach, present method).

$39.1 \quad 31.2$

(9)

(27)

(12)

38.9

Item II: Give free tax to automobile companies that import cars which achieve antipollution standards (economic

9.1 incentives).

(2)

(3)

(2)

Item III: Give free tax to automobile companies that import cars which achieve antipollution standards, then impose heavy tax penalty on auto companies which import cars that do not achieve antipollution standards (a combination of incentive 26.1 and penalty system).
24.1
9.1
21.8

(6) (19) (2)

Item IV: Levy heavy tax penalties on consumers who purchase automobiles which do not meet

Item V: Give free tax to consumers who purchase automobiles that achieve antipollution standards.

Item VI: Government should do nothing.

*Numbers in parentheses refer to number of respondents.

$* X^{2}=38.50$ with $45 \mathrm{df}$. Critical $X^{2}$ value at .05 level $=61.63$.

Table 5 shows that individually, the low income group selected item I (pass and enforce laws that require automobile importers to import cars which meet antipollution standards) as the best alternative measure to control automobile pollution, 39.1 percent. The middle income group chose the same control measure by 31.2 percent; and the high income group by 54.5 percent. The second choice of all groups was item V, 22.6 percent (give free tax to consumers who purchase automobiles that achieve antipollution standards). The $X^{2}=38.50$ with $45 \mathrm{df}$. Critical value at 0.05 level $=61.63$ confirmed that the difference in preference to automobile control measures between low and high income motorists was not statistically significant hence the hypothesis was retained. 


\section{Discussion of Findings}

The questionnaire administered to the subjects was designed to provide a consensus of the research respondents regarding policy alternatives relative to automobile pollution control. The major finding of the study was that majority of the respondents $(38.7 \%)$ preferred item I, "Pass and enforce laws that require automobile importers to import cars which meet antipollution standards (the regulatory approach, present method). One possible explanation for this result is probably, the subjects feel that a car's real emissions should be checked by the manufacturers or importers and not drivers on the road. This finding goes against the conventional wisdom that most auto emissions control problems are caused by vehicle owners who do not maintain their cars properly (Chen, 1999). This finding which emphasizes regulatory policy, tends to promote excessive government interference in the process of decision making. It also tends to impose cumbersome and rigid regulations which are often highly uneconomic for both importers and drivers.

The least preferred items to control automobile emissions were items II, IV and VI with the same percentage margin, 5.6 percent. The demographic variable of age made a significant difference in the choice of items to control automobile emissions. Subjects under 35 years old preferred item III, by 36.0 percent (give tax free to automobile companies that import vehicles which achieve antipollution standards....) All other age groups preferred item I (the present method). Item I was the choice of both sex groups (male subjects $=37.6$ percent; female $=41$ percent). These two findings are in corroboration with the findings of Howard-Clinton (2005) and Harrison (2005) who concluded from their findings that age made a significant difference in the choice of policy choices to control environmental pollution while there was no significant difference between male and female respondents in preference to environmental pollution control measures.

\section{Conclusion}

Based on the results of the data analysis, the following conclusions were drawn:

1. The majority of the respondents preferred the passing and enforcing of laws that require automobile importers to import only automobiles which meet antipollution standards as the best alternative to control automobile emissions. This implies that the problem of automobile emissions is traceable to the manufacturers and importers.

2. The second choice of the majority to control automobile emissions is item V, "Give free tax to consumers who purchase automobiles that achieve antipollution standards."

3. The demographic variable age made a significant difference in the choice of items to control automobile emissions.

\section{Recommendations}

Based on the conclusions of the study the following recommendations were proffered:

1. Air Resources Commission should be established in Nigeria with the responsibility of regulating emissions from all fueled and gasoline burn engines imported into the country and importers whose automobiles pass emission tests should be given free tax.

2. Law makers in Nigeria should develop emissions regulations for personal and commercial vehicles that have been on the road for 5 years.

3. Emission testing for all personal and commercial vehicles should be one of the conditions for annual renewal of vehicle particulars.

4. Carbureted automobiles should be banned from being imported into Nigeria. Fuel injected automobiles should be encouraged. 
5. Regular scheduled vehicle inspections to identify, individual vehicles for repair should be initiated, and drivers who fail to effect necessary repairs should be sanctioned.

\section{References}

Arbor, A. (2009). Air pollution from highway motor vehicles and equipment. EPA National Vehicle and fuel emissions report.

Bordoff, F. (2011). Emission control systems. http//www. family car.com/classroom.emission. http.

Chen, A. (1999). Unexpected source of emissions control system failure. http://www./b/.gov/scienceArticles/Archive/auto-emissions-study.htm.

Council on Environmental Quarterly (1998). Municipal Waste. Washington D.C.

David, A. (2005). Innovation and technology policy: Lessons for emission control and safety Technology in the U.S. http:/Isapapers. pitt.edu/139..

Gallion, J. (2009). Emission standards on road vehicles and engines. http://www.diesel/net.com/standards/In/.

Harrison, D. (2005). Who pays for clean air? Cambridge: Ballinger Publishing Company.

Hines, L.G. (2006). Environmental issues, pollution and economic. New York: W.W. Norton and Company, Inc.

Huissein, A.G. (2000). Technical report on waste disposal for small communities. Amman. Jordan 6-9 November.

Howard-Clinton, E.D. (2005). Attitude in the Oklahoma City Area towards selected solutions to environmental problems. UMI Dissertation Services. Michigan: A Bell and Howell Company.

Koning, H.W. (1994). Air pollution in Africa. World Health Organization Magazine. Geneva.

Nworgu, B.G. (1991). Educational research: Basic issues and methodology. Ibadan: Wisdom Publisher Ltd.

Ogbodo, A. \& Ogunbunmi (1997). The earth, our home, our heritage, our future. The Guardian 18 (8578.21).

Oklahoma State Health Department (2005). Air pollution control regulations and guidelines. Oklahoma State Health Department Air Quality Service, September.

Sridher, M.K.C. (1994). Wastes environment and community health. Procedures of the National Sanitation Workshop organized by UNICEF/Federal Ministry of Water Resources.

Teniriwiro, A. (2011). Tougher auto emission standard. (http://english cri.cn/2946/176 @ 244647.htm)

U.S. Environmental Protection Agency Office of Mobile Sources (2007). Automobile emissions: An overview. EPA Fact Sheet.

Waldboth,G.T. (2008). Toxic actions of pollution. St. Louis: C.V. Mosby. 
